https://doi.org/10.25143/socr.16.2020.1.024-029

\title{
Representation of Creditors in Corporate Bankruptcy Proceedings
}

\author{
Remigijus Jokubauskas \\ ORCID: 0000-0003-4314-850X \\ Faculty of Law, Mykolas Romeris University, Lithuania \\ remigijus@jokubauskas.org \\ Mykolas Kirkutis \\ ORCID: 0000-0001-6317-177X \\ Faculty of Law, Mykolas Romeris University, Lithuania \\ mkirkutis@gmail.com
}

\begin{abstract}
The article focuses on representation of creditors in corporate bankruptcy proceedings. It discusses social and economic needs for creditor representation in corporate bankruptcy proceedings and why it shall be effective. Also, the authors analyse how creditors can participate and vote in meetings of creditors. This article focuses on electronic voting and virtual meetings of creditors. The authors assess what regulation of electronic voting and virtual meetings exist in various bankruptcy laws and how it shall be compatible with the main principles of bankruptcy law.
\end{abstract}

Keywords: corporate bankruptcy proceedings, electronic voting, virtual meetings of creditors.

\section{Needs for Effective Creditor Representation in Bankruptcy Proceedings}

The UNCITRAL Model Law on Insolvency requires that insolvency proceedings shall be effective. Creditor participation in bankruptcy proceedings is one of the main aspects of this goal. It is recognised that in the absence of a coordination mechanism between creditors, they may delay the exercise of their rights and other creditors may simply waive their rights [3]. Corporate insolvency law should ensure a more efficient 
and creditor-friendly regime [1]. The principle of effectiveness is also recognised in national corporate bankruptcy laws. For example, Article 6 (5) of the Insolvency Law of the Republic of Latvia establishes the principle of efficiency (procesa efektivitätes princips) which means that the measures used to achieve the objectives of the process must be the most efficient and require the least cost. Article 3 (1) of the Law on the Insolvency of Enterprises of the Republic of Lithuania lays down the principle of effectiveness (efektyvumo principas), which means that in insolvency proceedings balance must be struck between the interests of the legal person in financial difficulties and the creditors in order to maximise creditor claims within a reasonably short period of time. Therefore, the legislator shall seek to establish such model of corporate bankruptcy proceedings which would ensure effective creditor participation in such proceedings.

Bankruptcy is a collective proceeding in which all debtor's creditors participate. Bankruptcy proceedings are characterised by court activity and protection of public interest [5]. For instance, Article 3 (4) of the Law on the Insolvency of Enterprises of the Republic of Lithuania establishes that a court may, on its own initiative, oblige parties to the insolvency proceedings to take process, collect evidence and monitor actions of the parties to the insolvency proceedings in order to ensure the efficient conduct of insolvency proceedings and public interest. Thus, one may ask why representation of creditors in corporate insolvency proceedings is needed at all.

It would be difficult to find a country which does not establish some forms of representation of creditors in bankruptcy proceedings. Nevertheless, the laws on bankruptcy proceedings are usually silent on the needs for the representation of creditors. For example, in U.S. corporate bankruptcy law, the purpose of a creditor committee is to protect interests of unsecured creditors [2]. A meeting of creditors is defined as a "statutory watchdog" which has the power to supervise the activities of the company's governing bodies, to consult with the debtor and to require the appointment of an administrator [2].

In Germany, interests of creditors are represented and defended at meetings and committees. A meeting of creditors is a necessary body in bankruptcy proceedings for the exercise of the creditors' self-government functions (Selbsterwervaltung Befugnisse) [7]. A committee of creditors is considered an optional body for the provision and monitoring of assistance (Unterstützung) to the insolvency administrator (Überwachung). In Lithuanian bankruptcy law, a meeting of creditors is perceived as a self-governing body of creditors.

Also, it has been widely accepted that bodies which represent creditors play an important role in bankruptcy proceedings and provide "double protection" [6]. A meeting of creditors can supervise the functions of the insolvency administrator, give creditors the opportunity to speak on significant issues, and transparency of its activities is an important condition for a legitimate meeting of creditors [6]. Therefore, meetings of creditors essentially perform a certain function of "checks and balances" in assessing decisions of insolvency administrator in bankruptcy proceedings. 
Creditors shall be involved in decision-making process during a meeting of creditors. All creditors have the right to be heard on the matters to be discussed at the meeting of creditors. Often creditors are experienced businesspersons who can share their knowledge and help a creditor to efficiently use debtor's resources or even restore solvency. Thus, there are plenty of social and economic reasons why creditors shall be represented in corporate bankruptcy proceedings.

\section{Participation and Voting in Meetings of Creditors}

Bankruptcy law shall establish how creditors can gather and vote on certain issues in bankruptcy proceedings. Various models exist in practice. Creditors can vote and (or) participate in meetings of creditors in several ways: (a) in person (a physical meeting), (b) by post or electronically, (c) in a virtual meeting. The authors have assessed these models within the article.

In practice, usually physical meetings of creditors are organised. In such case all creditors gather in a certain place at a certain time to discuss and vote on certain questions related to corporate bankruptcy proceedings. Obviously, such procedure requires additional costs and spend time in meetings. The efficiency of such model is rather low and does not contribute to the need for the efficient bankruptcy proceedings.

Another possibility which is recognised in various bankruptcy laws is voting by electronic means without participation in person at the meeting. In such case creditors can choose not to come to the creditors' meeting, but instead submit their votes via electronic means. Such procedure is beneficial if the creditors only seek to vote on certain matters without participation in a meeting. There are some examples in the national laws how creditors can vote by electronic means. For instance, the Insolvency Rules of England and Wales Rules 2016 regulate certain aspects of electronic creditors' voting. According to these rules, electronic voting includes any electronic system which enables a person to vote without the need to attend at a particular location to do so. Where the decision procedure uses electronic voting, (a) the notice delivered to creditors must give them any necessary information as to how to access the voting system including any password required; (b) except where electronic voting is being used at a meeting, the voting system must be a system capable of enabling a creditor to vote at any time between the notice being delivered and the decision date; and (c) in the course of a vote the voting system must not provide any creditor with information concerning the vote cast by any other creditor.

Electronic voting in meetings of creditors is also recognised in the Republic of Lithuania. Article 51 (4) of the Law on the Insolvency of Enterprises of the Republic of Lithuania establishes that creditors can vote in advance (before the creditors' meeting) if such procedure is established. Thus, the law does not require creditors to vote and/or participate in a certain way but allows them to choose to vote electronically. So far, 
the legal regulation does not establish how creditors shall vote, but only provides what electronic voting is possible.

Finally, another option is creditor participation and voting in virtual meetings of creditors. The advantages of such meetings are vivid since creditors and other persons do not have to spend costs and waste time to come to the meeting. Instead all creditors can participate and vote in such meetings without participation in person (physically) and participate in virtual (online) creditor's meetings. Some comparative aspects of such procedure can be found in corporate law. For example, Article 8 (1) of the Directive 2007/36/EC of the European Parliament and of the Council of 11 July 2007 on the exercise of certain rights of shareholders in listed companies establishes that Member States shall permit companies to offer their shareholders any form of participation in the general meeting by electronic means, notably any or all of the following forms of participation: (a) real-time transmission of the general meeting; (b) real-time two-way communication enabling shareholders to address the general meeting from a remote location; (c) a mechanism for casting votes, whether before or during the general meeting, without the need to appoint a proxy holder who is physically present at the meeting. Thus, a shareholder meeting can be held virtually if a real time transmission is established.

The Insolvency Rules of England and Wales Rules 2016 regulate virtual meetings of creditors. According to these rules, where the decision procedure uses a virtual meeting a notice delivered to creditors must contain: (a) any necessary information as to how to access the virtual meeting including any telephone number, access code or password required; and (b) a statement that the meeting may be suspended or adjourned by the chair of the meeting (and must be adjourned if it is so resolved at the meeting). Thus, this law does not establish any requirements for how creditors can participate and vote in virtual creditors' meetings but requires providing creditors all relevant information regarding the meeting and notification that meeting can be adjourned or postponed. Such requirements are relevant to ensure procedural guarantees for the creditors and possibility to participate in the meeting.

Also, some rules on virtual creditors meetings are found in other states. For instance, Article 51 (5) of the Law on the Insolvency of Enterprises of the Republic of Lithuania establishes that creditors may be given the opportunity to attend meetings and vote by electronic means, provided that security of the information transmitted is ensured and the creditor can be identified. Thus, the law does not establish certain procedure and technical tools how creditors can participate and vote in virtual meetings, but rather gives guidance how it should be organised. First, the law requires that transmitted information shall be secured. In general, only creditors and other certain persons in bankruptcy proceedings have the right to participate in meetings and get acquainted with information. Similarly, in virtual creditors' meetings only the persons who have the right to participate in meetings can participate. In this way the legislator requires to secure all information of creditors' meetings and it should not be available to other persons. Nevertheless, in practice this requirement can be difficult to implement. 
For instance, if the videoconference is organised, virtually everyone can listen to the conference in the premises of any of the persons who have the legal basis to participate in it. Furthermore, the law does not regulate possible technical issues of virtual meetings. For instance, what happens if some participants of the meeting lose connection to the virtual meeting due to technical problems. Secondly, the law requires that the creditor in the creditors' meeting shall be identified. In practice in should not raise difficulties since there is a list of creditors whose claims are approved by the court and the chairperson of the meeting or an insolvency administrator can check the identity of the person.

These examples of virtual meetings of creditors and electronic voting reveal that these means can be used in bankruptcy proceedings and they can contribute to the effectiveness of this proceedings. Also, the authors suggest the regulation of these models shall establish clear instruction and information of how creditors can use such systems (for instance, what programmes shall be used). Also, the regulation shall ensure equality of creditors and give equal chances for creditors to vote electronically or participate and vote in virtual meetings. Moreover, virtual meetings shall be recorded and used as an electronic evidence in case a dispute arises in the court [4].

\section{Conclusion}

Bankruptcy laws shall establish creditor representation model which is efficient and creditor-friendly, allow the creditors to avoid additional costs. One of the major aspects of effective creditor representation is effective model of participation and voting in meetings of creditors.

The authors found that voting by electronic means and participation and voting in virtual meetings of creditors significantly contribute to the efficiency of bankruptcy proceedings. There are some examples of the national laws which establish possibilities for creditors to vote by electronic means and participate and vote in virtual meetings. Nevertheless, virtual meetings raise certain challenges. For instance, security of the transmission of information, secrecy of voting, equal possibilities for all creditors to participate and vote in such meetings.

\section{Kreditoru pārstāvība korporatīvā bankrota procedūrās}

\section{Kopsavilkums}

Šajā rakstā par kreditoru pārstāvību korporatīvā bankrota procedūrās tiek apspriestas kreditora pārstāvības sociālās un ekonomiskās vajadzības korporatīvās bankrota procedūrās un to efektivitāte, kā arī tiek analizēts, kā kreditori var piedalīties un balsot kreditoru sapulcēs. Šajā rakstā tiek akcentēta elektroniskā balsošana un virtuālās 
Remigijus Jokubauskas, Mykolas Kirkutis. Representation of Creditors

in Corporate Bankruptcy Proceedings

kreditoru sanāksmes. Autori izvērtē, kāds regulējums attiecībā uz elektronisko kreditoru balsošanu un virtuālajām sanāksmēm pastāv dažādos likumos par bankrotu un kā tam jābūt saderīgam ar galvenajiem bankrota likuma principiem.

Atslēgvārdi: korporatīvā bankrota procedūras, elektroniskā balsošana, virtuālās kreditoru sanāksmes.

\section{Literature}

1. European Commission. (2015). Commission staff working document "Feedback Statement on the Green Paper "Building a Capital Markets Union"”, Accompanying the document "Communication from the Commission to the European Parliament, the Council, the European Economic and Social Committee and the Committee of the Regions", "Action Plan on Building a Capital Markets Union". SWD/2015/0184 final (EU publications, 2015).

2. Harner, M. M., Marincic J. (2011). Committee Capture? An Empirical Analysis of the Role of Creditors' Committees in Business Reorganizations, Vanderbilt Law Review, 64(3).

3. Impact assessment study on policy options for a new initiative on minimum standards in insolvency and restructuring law. (2017). (EU publications, 2017).

4. Jokubauskas, R., Świerczyński, M. (2020). Impact of the Council of Europe Guidelines on Electronic Evidence in Civil and Administrative Law. Global Journal of Comparative Law, 9(1).

5. Višinskis, V., Jokubauskas, R. (2019). The Role of Courts in Corporate Insolvency Proceedings. Jurisprudence, 26(2).

6. Westbrook, J. L. et al. (2010). A Global View of Business Insolvency Systems. Martinus Nijhoff Publishers.

7. Zimmermann, W. (2015). Grundriss des Insolvenzrechts (Eng. Outline of bankruptcy law). C. F. Müller. 